\title{
'I am proud of them all \& we all have suffered': World War I, the Australian War Memorial and a family in war and peace
}

\author{
ALEXANDRA MCKINNON
}

Five members of the Corney family served in World War I. Four returned. The impact of this loss - and the losses suffered by thousands of Australian families during the war-lingers in archival records. This article focuses on Rebecca Corney (1862-1943) and her evolving relationship with the Australian War Memorial (AWM). Corney saw three sons, a daughter and a son-in-law serve. Her middle son, Lieutenant Hubert Hume Corney, known generally as 'Hume', was killed in action at Broodseinde Ridge in 1917. Extending from 1927 to 1942, Rebecca Corney's correspondence with the AWM provokes a reconsideration of several objects displayed in its galleries. Her correspondence reflects a family profoundly affected by World War I, and experiences of grief and loss that extended beyond the confines of the conflict. This article presents a biographical profile of one family and a tentative exploration of the broader impact of individual grief on the development of archival records relating to World War I. Focusing on engagement between Australian families and the AWM, it explores how families engaged with memorymaking and with the state in the aftermath of the war. It includes a biography of the Corney family prior to and during World War I, an examination of the collecting processes of the AWM and a consideration of the impact of these donations. Some of these donations remain on display today but are presented in a different context to that in which they were donated.

\section{A family history}

The basic details of the Corney family are found in official records and newspaper articles. Rebecca Louisa (née Robertson) was born in Kyneton, Victoria, to Frank and Rebecca Louisa (née Kennan) Robertson. Her father was an early settler in the region, emigrating from Scotland before $1858 .{ }^{1}$ In 1885 , she married Walter Thomas

1 'Marriages', The Argus, [Melbourne], 17 December 1858, trove.nla.gov.au/newspaper/article/7306507. 
Corney at St Stephen's Church, Richmond. ${ }^{2}$ Their first child, Walter Robertson, ${ }^{3}$ was born soon after, at Wilcannia, NSW. Two of their other children were also born there: Charles (Charlie) Frederick (b. 1891) ${ }^{4}$ and Hubert Hume (b. 1892). ${ }^{5}$ Another two children, Kathleen Rebecca (b. 1889) ${ }^{6}$ and Frank Robertson (b. 1891), ${ }^{7}$ were born in Melbourne. In 1894, a partnership between Walter Thomas Corney and two other men trading as storekeepers at Wilcannia was dissolved; ${ }^{8}$ some time after that, the family moved to Kyneton. Walter travelled to Western Australia and, according to his obituary, became a 'well-known identity of Coolgardie in the boom days', ${ }^{9}$ but the rest of the family remained in Kyneton. In about 1910, Rebecca became the first secretary of the local branch of the Australian Women's National League (AWNL), a conservative, antisocialist women's organisation. ${ }^{10}$

At Kyneton, the Corney family was actively involved in the local community, as newspaper articles and announcements in the Kyneton Guardian reflect. The children attended Kyneton state school ${ }^{11}$ and regularly appeared in the lists of attendees for local dances and activities. Hume became secretary and librarian of the local Sunday school. ${ }^{12}$ Frank, the youngest son, went on to attend the Royal Military College, Duntroon, while Kathleen trained as a nurse. She married John Robertson (Jim) Duigan, a pioneer aviator responsible for the first Australian-made aircraft, at St Paul's Anglican Church, Caulfield, in $1913 .{ }^{13}$ In their father's absence, she was given away by Hume, with whom she had a particularly close relationship. ${ }^{14}$ Hume joined the local branch of the National Bank upon graduation from school. In an obituary published in the Kyneton Guardian on 26 February 1918, friends described him as 'kindly and cheery', but also 'quiet and retiring'. ${ }^{15}$

\footnotetext{
2 Victorian Registry of Births, Deaths and Marriages [hereinafter Victorian BD\&M], Registration no. 4073/1885. 3 New South Wales Registry of Births, Deaths and Marriages [hereinafter NSW BD\&M], Registration no. 35195/ 1886.

$4 \quad$ NSW BD\&M, Registration no. 38018/1891.

NSW BD\&M, Registration no. 38571/1892.

Victorian BD\&M, Registration no. 1906/1889.

Victorian BD\&M, Registration no. 7064/1895.

'Notice of Dissolution of Partnership', New South Wales Government Gazette, 26 June 1894, trove.nla.gov. $\mathrm{au} /$ newspaper/article/222340708? search Term =Walter\%20Thomas\%20Corney\&searchLimits=l-state=New+ South+Wales.

9 'Obituary: Two Well-Known Mining Men', Western Argus, [Kalgoorlie, WA], 20 August 1918, trove.nla.gov. au/newspaper/article/34188302.

10 'Social and Personal: A Great Little Worker', The Age, [Melbourne], 4 December 1937, trove.nla.gov.au/ newspaper/article/205550063.

11 'High School Council', Kyneton Guardian, 7 December 1916, trove.nla.gov.au/newspaper/article/129600177.

12 'Lieut. Hume Corney, M.M.', Kyneton Guardian, 7 March 1918, trove.nla.gov.au/newspaper/article/129609648.

13 Victorian BD\&M, Registration no. 8762/1913; F.J. Kendall, 'Duigan, John Robertson (1882-1951)', Australian Dictionary of Biography. Volume 8 (Canberra: National Centre of Biography, The Australian National University, 1981), adb.anu.edu.au/biography/duigan-john-robertson-6036/.

14 'Mr. J.R. Duigan to Miss R. Corney', Punch, [Melbourne], 4 December 1913, trove.nla.gov.au/newspaper/ article/176551916.

15 'Fallen Upon the Field of Honor', Kyneton Guardian, 26 February 1918, trove.nla.gov.au/newspaper/ article/129609488.
} 
World War I interrupted these daily routines. As the war progressed, many members of the Kyneton community enlisted for service overseas, including the four Corney siblings. Hume joined the Australian Imperial Force as a private in May 1915 and left Australia in July 1915 aboard the transport ship Demosthenes. ${ }^{16}$ Rebecca later wrote of her grief as she waved goodbye from the shore; in total, she would watch five of these transports leave Australia, as three sons, one daughter and a son-in-law embarked for service overseas. ${ }^{17}$ Hume served with the 24 th Battalion at Gallipoli, where he was badly wounded in the leg shortly before the evacuation. After recovering in hospital in Alexandria, he proceeded to France. ${ }^{18}$ As a graduate of Duntroon, Frank was commissioned as an officer in July 1915 and embarked for service overseas in November that year. ${ }^{19}$ He was one of three Duntroon graduates from Kyneton to enlist and the Melbourne Herald reported that the 'three Kyneton boys' had 'made good'. ${ }^{20}$ Frank served with the 25 th Battalion at Gallipoli and on the Western Front, before being transferred to the 26th Battalion in October $1918 .^{21}$ Charlie joined his brothers in April 1916 and served with the 101st Howitzer Battery. ${ }^{22}$ Kathleen volunteered in hospitals in London, on the condition that if her husband or brothers were wounded, she would be allowed to go off duty. ${ }^{23}$ Duigan enlisted with the Australian Flying Corps in March 1916 as a lieutenant. ${ }^{24}$ The eldest brother, Walter, remained at home.

The home front and the battlefield were closely connected. As the war continued, a group of young Kyneton women formed the Coo-ee Club, which raised funds to assist soldiers from the local district. ${ }^{25}$ Musical programs and charity auctions helped the club collect cigarettes and socks for soldiers serving abroad. The Kyneton Guardian reported that Hume and another soldier had received their Christmas presents from the Coo-ee Club; from the trenches, the men thanked the people of Kyneton for the reminder of home. ${ }^{26}$ The newspaper provided frequent updates on local soldiers and published accounts from men serving overseas. Hume described trench raids, artillery fire and the aerial battles overhead, alongside lighter stories and

\footnotetext{
16 Corney, Hubert Hume, HMAT Demosthenes, 16 July 1915, AWM Embarkation Roll.

17 Letter from Rebecca Corney, 26 November 1936, AWM93 12/11/548.

18 Corney, Hubert Hume, National Archives of Australia [hereinafter NAA], B2455.

19 Carney [Corney], Frank Robertson, HMAT Wandilla, 9 November 1915, AWM Embarkation Roll.

20 'Kyneton Proud of Record: Many Honors Are Won', The Herald, [Melbourne], 21 March 1918, trove.nla.gov.au/ newspaper/article/242511378.

21 Corney, Frank Robertson, NAA: B2455.

22 Corney, Charles Frederick, NAA: B2455.

23 Letter from Rebecca Corney, 26 November 1936, AWM93 12/11/548. This was also referenced in various newspaper accounts.

24 Corney, Duigan, NAA: B2455.

25 'Coo-ee Club Social', Kyneton Guardian, 3 May 1917, trove.nla.gov.au/newspaper/article/12958 6086/14850308.

26 'Mostly About People: Thanks for Xmas Gifts', Kyneton Guardian, 20 February 1917, trove.nla.gov.au/ newspaper/article/129584602.
} 
descriptions of 'sausage-shaped' observation balloons. ${ }^{27}$ This writing was published alongside other local news from the town, serving to emphasise a connection between the inhabitants of Kyneton and the men serving overseas. Accounts published in the newspaper were conscious of their intended audience, which included both families anxiously waiting for news of the front and soldiers searching for reminders of home, reading excerpts forwarded from family members. In December of that year, Hume wrote that he had received a parcel from the Red Cross only to discover that the pair of socks he received had, by chance, been made by the Women's Patriotic Committee in Kyneton. ${ }^{28}$ The home front echoed throughout these written reflections.

By 1915, Rebecca Corney was president of the St Kilda girls' branch of the AWNL but retained close connections to her former home. Kyneton-born women held a reunion at the AWNL conference in Melbourne in September 1915 and 'gravitated together very naturally during recess, and social reunion hours and reminiscences of the old days at school in Kyneton were freely indulged in'. ${ }^{29}$ In 1917, the Kyneton branch of the AWNL and local Red Cross workers organised a meeting at the Mechanics' Institute. ${ }^{30}$ The meeting emphasised the impact of the conflict on local families and offered a vote of congratulations to the families of local men who had received decorations for bravery, including Frank and Hume. There was specific recognition of Corporal Alexander Stewart Burton, VC, born in Kyneton, and Lieutenant Rupert Vance Moon, VC, who had been educated at Kyneton Grammar School. Neither had family remaining in the town, but they were understood as local men, nonetheless. Attendees were identified by their relationship to men on active service, furthering their link to those serving overseas.

On the Western Front, Hume and Frank earned the Military Medal and Military Cross, respectively, on the same day as their paths briefly crossed at Pozières. After his unit came under heavy fire, Hume volunteered as a stretcher-bearer, helping bring wounded men off the battlefield. He carried men across open ground to the dressing station, passing through heavy shellfire. ${ }^{31}$ As he prepared to lead the search for wounded men, he encountered a group from the 25th Battalion. Hume recognised their commanding officer as Frank, who had been badly wounded in the hand, but had remained with his men in the line for 12 hours. The brothers wrote to their mother about this chance meeting ${ }^{32}$ and Hume sent her his stretcher-

\footnotetext{
27 'Raiding the Enemy's Trenches', Kyneton Guardian, 26 August 1916, trove.nla.gov.au/newspaper/ article/129597664.

28 'For King and Country', Kyneton Guardian, 18 December 1915, trove.nla.gov.au/newspaper/article/129608147.

29 'Mostly About People: Reunion of Kyneton-Born Women', Kyneton Guardian, 14 September 1915, trove.nla. gov.au/newspaper/article/129606221.

30 'Soldiers' Relatives and Red Cross' Workers' Reunion', Kyneton Guardian, 21 June 1917, trove.nla.gov.au/ newspaper/article/129587302.

31 Corney, Hubert Hume, NAA: B2455.

32 Letter from Hubert Hume Corney to his mother, 7 April 1917, AWM 2DRL/0947.
} 
bearer armband for safekeeping. ${ }^{33}$ When this news was announced back home at the opening of a Christmas fundraiser to support the war effort, students at Kyneton state school gave the brothers a round of applause. ${ }^{34}$

Hume was subsequently commissioned lieutenant. In correspondence with Base Records, his commanding officer wrote that he was known to all 'as an Officer of exceptional ability', with 'indomitable courage and energy'. ${ }^{35}$ He was transferred to the 21st Battalion shortly before British command shifted its focus north towards the relatively higher ground of Flanders and what would become known as the Third Battle of Ypres, or Passchendaele. On 9 October 1917, Hume led his men forward during an attack on Broodseinde Ridge. ${ }^{36}$ The unit came under heavy fire and he was subsequently reported missing. Another Kyneton man serving with the same battalion, Sergeant James Hutcheson Sandford, was also reported missing during the attack, and the Kyneton Guardian reported the double blow for the town. ${ }^{37}$ Rebecca received the news of Hume's loss from her local clergyman. ${ }^{38}$ In a letter forwarded to her, his commanding officer wrote that Hume was last seen 'gallantly leading his men during the attack' ${ }^{39}$ - a phrase repeated in later obituaries. In an official report, Hume's commanding officer added: 'He knew how to live, and, I feel sure, he knew how to die. ${ }^{40}$

After the war, the surviving members of the Corney family returned to Australia. Their father had died in Perth of an unspecified illness a few months after Hume's death. ${ }^{41}$ Frank and Duigan had each been wounded in action several times, and Duigan had earned the Military Cross for action in an aerial battle over VillersBretonneux in May 1918. ${ }^{42}$ Frank remained with the Australian forces after the war and married a British nursing sister, Lucy Keziah Gooch, in 1919. ${ }^{43}$ For Rebecca, the loss of her son was devastating. Her early correspondence with Australian military authorities offers an insight into the broader impact of this conflict and is continued in her later contact with the AWM. She wrote repeatedly to General

33 Letter from Hubert Hume Corney to his mother, 4 December 1916, AWM 2DRL/0947.

34 'Children's Bazaar: Kyneton College Pupils—Successful and Enjoyable', Kyneton Guardian, 2 December 1916, trove.nla.gov.au/newspaper/article/129600006.

35 Corney, Hubert Hume, NAA: B2455.

36 Corney, Hubert Hume, AWM Australian Red Cross Wounded and Missing Files.

37 'Mostly About People: Lieut. Hume Corney' and 'Sergt. J.H. Sandford', Kyneton Guardian, 17 November 1917, trove.nla.gov.au/newspaper/article/129590777.

38 Corney, Hubert Hume, Letter from Rebecca Corney, 22 February 1918, NAA: B2455.

39 Letter from Major Henry A. Crowther, 21st Battalion, to General Sir William Birdwood, 15 January 1918, AWM 2DRL/0947. This was republished in the Kyneton Guardian ('Lieut. Hume Corney, M.M.').

40 Corney, Hubert Hume, Letter from Major Henry A. Crowther, 21st Battalion, to General Sir William Birdwood, 6 May 1918, NAA: B2455.

41 Western Australia Registry of Births, Deaths and Marriages, Registration no. 757/1918.

42 Duigan, John Robertson, NAA: B2455.

43 Corney, Frank Robertson, NAA: B2455. 
William Birdwood and the Australian Red Cross Wounded and Missing Bureau for information and had her local member of the House of Representatives, Sydney Sampson, contact Base Records on her behalf. In February 1918, she stated simply:

If you can tell me any particulars or that I shall know more in course of time, I will be very much obliged-for I cannot believe that he is dead. ${ }^{44}$

Corney also wrote to the French general Paul Pau, who visited Australia in September 1918. Describing her three sons, she begged for any information about Hume's burial and emphasised the shared losses of French and Australian families:

The third is the one I want you to help me with for I fear he will never come back; reported 'missing' afterwards 'officially killed in action' ... I give his bright young life willingly to die for France and am proud to be his mother, but it would so comfort me to know he has a grave and that it is well cared for ... I enclose the photo of my 'missing' boy with all particulars which may help you to find his grave or perhaps even to find if he is alive. ${ }^{45}$

Later Corney wrote that her daughter, Kathleen, had searched the hospitals in England, interviewing men from the 21st Battalion, and had written to the Wounded and Missing Bureau. ${ }^{46}$ No further information was forthcoming. After the Armistice, Rebecca continued to write to Base Records almost monthly, declaring:

Kindly pardon this lengthy letter but I cannot help it my heart is so full of my poor son ... I will always search for him, as long as I am alive. ${ }^{47}$

In 1920, Hume's body was recovered from the former battlefield, identified by his paybook in the pocket of his tunic. He was subsequently buried at Passchendaele New British Cemetery. ${ }^{48}$ After an unsuccessful request for the paybook to be returned, Corney's correspondence with Australian military authorities abruptly ended.

\section{Collecting records}

Amid the devastation of World War I, the AWM began the process of writing the official histories of Australia during the conflict. The Australian War Records Section was established on 16 May 1917. Archives remain a central element of the AWM, alongside its function as both memorial and museum. With Lieutenant John Linton Treloar appointed as officer-in-charge, the section was formed in the interests of the national history of Australia and in order that Australia may have

44 Corney, Hubert Hume, Letter from Rebecca Corney, 22 February 1918, NAA: B2455.

45 Corney, Hubert Hume, Letter from Rebecca Corney, 1 January 1919, NAA: B2455. A short translation in

French was added by Base Records, stating, in effect, 'she wants to find the grave of her son'.

46 Corney, Hubert Hume, AWM Australian Red Cross Wounded and Missing Files.

47 Corney, Hubert Hume, Letter from Rebecca Corney, 9 December 1919, NAA: B2455.

48 Corney, Hubert Hume, Grave concentration record, 22 April 1920, Commonwealth War Graves Commission. 
control of her own historical records' ${ }^{49}$ Soon after the war had started, Charles Bean informed the Department of Defence that he intended to 'undertake to write from [his notes and] letters the story of the part Australians [would] play in the war. ${ }^{50}$ This history could not, however, be written solely in his own words, but would instead be drawn from the experiences of those who served on the battlefields of World War I. Within the global catastrophe of the war, Bean saw the opportunity for a distinctively Australian story. Writing this history would require records from the veterans who had returned home, but also from those who had not.

As the process of writing the official histories began, the AWM set out to contact family members of the dead who might hold records of value to this work. The task began with a three-month trial in 1927 and continued until the mid 1930s. While most of those contacted had not been involved directly in the conflict, they remained profoundly affected by its consequences. Their responses were filed as 'AWM93 12/11-Bazley's circularisation of next-of-kin', and this archive remains an unusual record. Arthur Bazley was Charles Bean's assistant and a central figure in the establishment of the AWM. He had been given the task of the roll of honour circulars, ${ }^{51}$ which had been sent by the Department of Defence to next of kin, requesting biographical details of the dead that would assist in compiling the roll of honour and the official histories. Some respondents replied that they possessed letters, diaries, documents or other ephemera of lives abruptly ended on foreign soil. For these relatives, Tanja Luckins has suggested that the artefacts served as substitutes for the absent bodies of the dead, who were scattered on battlefields a world away from Australia. ${ }^{52}$ For the AWM, however, the mementos of lost loved ones were also a valuable historical resource, and Bazley sought to negotiate with these families for access to their records. The fact that it was the AWM that initiated contact, together with the breadth of wartime experiences the file series represents, distinguishes it from the broader collecting processes of the organisation.

Within the archives of the AWM, the file series has been little considered as an archive in its own right. Anne-Marie Condé has discussed the process of acquisition evident in the files and the emergence of the collections of both the AWM and the Mitchell Library in Sydney. ${ }^{53}$ In a study of 367 files, she explored records donated both by families and by returned soldiers, including some of the most

49 Michael McKernan, Here Is Their Spirit: A History of the Australian War Memorial, 1917-1990 (Brisbane: University of Queensland Press in association with the Australian War Memorial, 1991), 37.

50 Charles Bean, letter to Commander Pethebridge, Department of Defence, 16 October 1914, AWM38 3DRL 6673.78. Cited in McKernan, Here Is Their Spirit, 34.

51 McKernan, Here Is Their Spirit, 140.

52 Tanja Luckins, 'Collecting Women's Memories: The Australian War Memorial, the Next of Kin and Great War Soldiers' Diaries and Letters as Objects of Memory in the 1920s and 1930s', Women's History Review 19, No. 1 (February 2010): 21-37, doi.org/10.1080/09612020903444635.

53 Anne-Marie Condé, 'Capturing the Records of War: Collecting at the Mitchell Library and the Australian War Memorial', Australian Historical Studies 36, No. 125 (27 January 2009): 134-52. 
extensive files in the collection. She concluded that archival records held at the AWM record 'little of the complex and anxious processes by which the records came into the collection'. ${ }^{54}$ In Here Is Their Spirit, a history of the AWM, Michael McKernan referenced the series as part of the broader process of collection in the development of the institution. He profiled the first and last files in the series, using them as evidence of the 'strenuous efforts' made by Treloar 'to augment the official records by collecting personal records of men and women who had served in the war'. ${ }^{55}$ However, like Condé, he found that the impact of this file series on the broader collections of the AWM had been little considered. Beyond this process of acquisition, the records reflect not only the wartime experiences of their original owners, but also the subsequent experiences of their next of kin. They are thus significant as a reflection both of individual loss and of a broader national grief, with a lingering presence in the modern archive.

Rebecca Corney was among those who received an inquiry from the AWM, more than a decade after Hume had been killed in action. The subsequent correspondence extended from 1927 to 1942 and illustrates the shifting concerns and aspirations of potential donors. Corney appears to have been identified as a participant from her response to the roll of honour circular, which included a summary of Hume's service. The first letter to Corney was dispatched on 25 October 1927. Her responses give not only a sense of how her life had progressed in the postwar period, but also some of the reasons many families failed to respond to the AWM's initial requests. She initially responded on 11 December 1927, apologising for the delay and detailing her other obligations, which perpetuated the wartime voluntary work and emotional labour described by Bruce Scates in his article on 'The Unknown Sock Knitter'. ${ }^{56}$ Corney continued to play an active role with the AWNL:

[I] beg to state that I am a very busy woman, being the Hon. Sec. of the South Yarra Branch A.W.N.L. with over 500 members \& have not had any time to go through my late son's letters \& belongings-you can understand that I cannot send you anything in a hurry. ${ }^{57}$

She was also a council member of the Friendly Union of Soldiers' Wives and Mothers, which had been established as a support organisation during the war. This emphasis on work suggests that, while Corney's letters lingered on the past, her daily life could not; time moved inexorably forwards. In addition, Corney wrote that, while the AWM letter had been addressed to her, she needed to consider the attitudes of the broader family. She had written to Frank regarding his own letters, but they both believed that the private records she held would probably be of little

54 Condé, 'Capturing the Records of War'.

55 McKernan, Here Is Their Spirit, 140.

56 Bruce Scates, 'The Unknown Sock Knitter: Voluntary Work, Emotional Labour, Bereavement and the Great

War', Labour History, No. 81 (2001): 29, doi.org/10.2307/27516802.

57 Letter from Rebecca Corney, 28 July 1928, AWM93 12/11/548. 
use to historians or of interest to the general public. The same was true for Hume's records. Responding to further prompts from the AWM, she reaffirmed her position on 1 April 1928:

I have been looking through them, but do not think they are of sufficient importance: when he was a non-commissioned officer, all his letters were censored $\&$ then he was killed so soon after he gained his commission so you will understand that he was not able to write details or records of the war. ${ }^{58}$

The AWM also contacted Frank directly. On secondment to the Staff College, Camberley, he redirected communications to his mother, who had retained his war records. ${ }^{59}$ In the file series, Corney lists the records she held in her collection, vacillating between a desire to enshrine them in the AWM and a reluctance to part with letters and objects that were clearly of personal value. On several occasions, she sent an item from her collection, but each time asked for it to be returned to her. ${ }^{60}$

The responses contained in the series suggest the complicated emotions associated with the donation of records, balancing the obligations and emotions of daily life with concern for what form remembrance would take after living memory of the war had faded. For Corney, her family's wartime service was a source of both pride and loss, with remembrance linked to her family's individual experiences. She viewed Frank as her successor as holder of the family's records, and intended to leave 'all my papers letters, medals \&c to him', although she also stated that she would like the AWM 'to have some of them too' ${ }^{61}$ In 1929, however, she stopped writing to the AWM, which concluded that she was among the many who were either unable or unwilling to respond, and the file was subsequently closed.

In 1936, however, Corney reopened the correspondence. Her personal circumstances had changed and she was increasingly concerned about what would become of her family's records after her death. Frank had suffered a nervous breakdown, which prompted his early retirement, while Charlie had stopped speaking to other family members, which she attributed to a lingering effect of the war. Although she did not mention it, her oldest son, Walter, had also suffered a reverse in his fortunes, having been imprisoned for fraud in his employment as a bank manager. ${ }^{62}$ Corney emphasised the continuing impact of the war on each of her children who had served:

58 Letter from Rebecca Corney, 1 April 1928, AWM93 12/11/548.

59 Letter from Frank Corney, 11 May 1928, AWM93 12/11/548.

60 Letter from Rebecca Corney, 8 July 1929, AWM93 12/11/548.

61 Letter from Rebecca Corney, 1 April 1928, AWM93 12/11/548.

62 'Bank Manager's Lapse: Extraordinary Case- "Willing to Expiate Crime", The Argus, [Melbourne], 19 May 1923, trove.nla.gov.au/newspaper/article/2010018. 
[Charlie] who was not wounded at all, nor did he receive any decoration, but he did his duty \& gave up the management of a large station in Queensland ... to go to the war \& is never the same since-as he cannot settle down \& is always wandering around the back country. ${ }^{63}$

Both the AWM and the respondents understood that the donations were not only for the present, but also constituted a perpetual memorial. As with many correspondents, Corney emphasised that the records would not hold the same significance for future generations who lacked a direct experience of these losses; the dead would become an abstracted absence, rather than the individuals they had been in life. She sought advice from the memorial:

I now wish to send [the records] to you, whilst I am alive $\&$ able to sort them out $\&$ only send what is really suitable, as when I am gone, very likely everything will be destroyed, as unfortunately there are no grandchildren who would care for them. ${ }^{64}$

Her family's losses affected not only the dead, but also the living; the consequences of war were sustained not only by those who were sent to foreign battlefields, but also by those who remained at home and lived with the legacy of war. Through the loss of her son, and the service of her other children, Corney came to see a space for her entire family in the archives of the AWM.

Yet Corney remained reluctant to part with the records for the same reason as other respondents had agreed to donate records to the memorial: they were the last remnants of the dead. In 1928 she had explained that

they are too precious $\&$ as long as I am alive I like to have them with me-when I am gone, there is no place that I would like them to be. ${ }^{65}$

She had visited Hume's grave in Belgium in 1925, but remained preoccupied by his moment of death, continually revisiting the anxious months when she had hoped he had been taken prisoner, and the reality that 'he really was shot down $\&$ buried in the mud $\&$ his body not found till 2 years afterwards' ${ }^{66}$ Corney agreed to donate letters from her three sons to the AWM in 1936, and offered Hume's war medals in 1942. She also enclosed the commemorative medallion sent to her after his death and the 'little brass box that Queen Mary sent to all Anzacs in Christmas 1914 with her picture head on the lid \& M.M. on each side, ${ }^{67}$ in which the medals had been kept. Along with Hume's medals, Corney included the bullet that had passed through his leg when he was wounded at Gallipoli, which he had kept as

63 Letter from Rebecca Corney, 26 November 1936, AWM93 12/11/548.

64 Letter from Rebecca Corney, 15 November 1936, AWM93 12/11/548.

65 Letter from Rebecca Corney, 28 July 1928, AWM93 12/11/548.

66 Letter from Rebecca Corney, 1 April 1928, AWM93 12/11/548.

67 This was presumably a tin from Princess Mary's Christmas gift, which was originally intended for all Commonwealth forces serving on Christmas Day 1914. 
a memento. Her desire to donate these objects seemed to have been compounded by the 'awful War' ${ }^{68}$ that had begun in the interim, and she died less than a year after her final communication with the AWM. ${ }^{69}$

\section{Aftermath}

These records do not fundamentally change the histories of Australian service during World War I, but they contribute to a better understanding of the broader impact of the conflict. Letters home were being written not merely by a subject, but also to another. Records associated with the Corney family tell a broader story of loss; their brief responses hint at the continuing costs of war and the intricate networks that intertwined the home front and the battlefield. Corney ultimately donated a selection of letters from her three sons and objects from Hume. This included a 'gun metal band with Fleurbaix on it-1914-1916', 'some Turkish coins', 'little ornaments' and other items from 'a little tin box of souvenirs [Hume] had collected $\&$ sent home to [Rebecca] in his kit-bag' ${ }^{70}$

The collection of files in the AWM archives relating to the Corney family incorporates three small folders of personal records, numbered sequentially. ${ }^{71}$ Hume's is by far the most detailed and includes a small wallet containing leave passes and a prayer book inscribed: 'Hume dear with love \& best wishes from Mother.' The personal records are as much about who Hume was in death as who he was in life and can be divided into two sections: his letters to Corney and Corney's search for information about her son's death. There are newspaper cuttings from the Kyneton Guardian relating to the awarding of his Military Medal and Frank's Military Cross, an announcement of Hume's death and descriptions of the memorial services at the local school and church. There is also a collection of letters from General Birdwood and Hume's commanding officer after Corney's inquiries about an erroneous report that Hume had been taken prisoner. They reflect a story repeated in thousands of households across Australia, as families attempted to reconcile themselves with the term 'missing'.

Letters from the three Kyneton men focus on the home front. They received packages from the Coo-ee Club and various people in the town and Hume sent his mother news on local men serving abroad. For example, he wrote that Willie Hall ${ }^{72}$

\footnotetext{
68 Letter from Rebecca Corney, 25 February 1942, AWM93 12/11/548.

69 Victorian BD\&M, Registration no. 1247/1943.

70 Letter from Rebecca Corney, 8 July 1929, AWM93 12/11/548.

71 AWM 2DRL/0947, 2DRL/0948 and 2DRL/0949.

723323 Private William Wykes Hall, 21st Australian Depot Unit of Supply. Enlisted, 23 July 1915; returned to Australia, 18 January 1919.
} 
was 'looking very well $\&$ is in the A.S.C.' ${ }^{73}$ Vernon Rogerson ${ }^{74}$ 'came over with the 4th Reinforcements $\&$ is looking very well'; ${ }^{75}$ Walker Thomson ${ }^{76}$ 'took my Photo $\&$ said he would send it to [illegible]. He was very nice to me. ${ }^{77} \mathrm{He}$ thanked other writers for all the Kyneton news they enclosed and he visited the graves of the dead. Within the confines of what Hume was allowed by military authorities to write, there are hints of discontent with the war, particularly after he learned his brother had given up his position as the manager of a station in Queensland to enlist:

I am very sorry to hear that Charlie has enlisted. It is a great pity that he has to give up his position just when he was going to settle down. He is giving up a great deal $\&$ it is hard luck. ${ }^{78}$

Yet he downplays the impact of the war itself in these letters home. Hume described a bullet lodged in his leg as 'a slight wound in the leg, just above the ankle', ${ }^{79}$ and Frank pronounced his injured arm a 'very lucky' injury, although he reported: 'I cannot close my fist yet $\&$ cannot use two fingers very well, but that will all come in time. ${ }^{80}$

The records are as much a record of Corney herself as of her children's service, documenting her reimagining of the war in its aftermath and her search for understanding after Hume's death in action. There is no mention of the horrors of war such as shell shock or venereal disease. ${ }^{81}$ In the file folder of Charlie's personal records, several items have no connection to his own service, including a field postcard addressed to his mother from Charles Hladky, thanking her for the cigarettes sent as part of the Southern Cross Tobacco Fund, which had collected funds across Australia to supply tobacco, cigarettes and matches to soldiers serving overseas. ${ }^{82}$ Otherwise, Hladky had no connection to the other letters in the file, beyond his brief interaction with Corney.

\footnotetext{
73 Letter from Hubert Hume Corney to his mother, 4 September 1915, AWM 2DRL/0947.

742249 Private Vernon Rogerson, 24th Australian Infantry Battalion. Enlisted, 19 June 1915; killed in action, 5 August 1916.

75 Letter from Hubert Hume Corney to his mother, 12 March 1916, AWM 2DRL/0947.

76 Captain Walker Henderson Thomson, 29th Australian Infantry Battalion. Enlisted, 16 September 1915; returned to Australia, 15 February 1918.

77 Letter from Hubert Hume Corney to his mother, 17 April 1916, AWM 2DRL/0947.

78 Letter from Hubert Hume Corney to his mother, 12 March 1916, AWM 2DRL/0947.

79 Letter from Hubert Hume Corney to his mother, 25 December 1915, AWM 2DRL/0947.

80 Letter from Frank Robertson Corney to his mother, 31 October 1916, AWM 2DRL/0948.

81 Each of the three Corney brothers who enlisted was hospitalised with venereal disease while on active service. This is not mentioned in correspondence with their mother.

82 Southern Cross Tobacco Fund postcard from Charles Hladky to Rebecca Corney, undated, AWM 2DRL/0948; 1678 Corporal Charles Hladky, 24th Australian Infantry Battalion. Enlisted, 25 May 1915; returned to Australia, 31 January 1918.
} 
Among the donations was an improvised stretcher-bearer armband Hume had created on the battlefield at Pozières, during the action for which he was awarded the Military Medal. It is now on display as part of an exhibition on the role of stretcher-bearers at Pozières. ${ }^{83}$ Hume himself was never officially a stretcher-bearer and he forwarded the armband as part of a Christmas letter to his mother in 1916:

I am enclosing a little souvenir. It is not much, \& as you see was made by myself, but it was used by me doing my little bit in the Great Push. ${ }^{84}$

Corney explained her donation with a handwritten note, which is not included as part of the display:

Armlet for Stretcher Bearer made and sent by my son then Corporal H Hume Corney at battle of Pozieres 1916 when he was awarded the Military Medal and his brother Capt. F. R. Corney for work done at same battle the night before-the two brothers met for a few minutes as one was going out of the trenches and the other going on to the battlefield to gather up the wounded. R.L. Corney (Mother). ${ }^{85}$

The medals are no longer packed in the 'little brass box' alongside the bullet removed from Hume's leg; they have been removed from their original context. These artefacts remain as a record of the man to whom they were issued, but they no longer reflect the aspirations and experiences of a broader community.

Exploring how the archives of the AWM were developed is a means of understanding how commemoration has evolved. This file series occupies an unusual space within the historical record, testifying to a deliberate construction of the archive. It represents a process of exchange between the AWM and families, shaping an emerging collection and, accordingly, the national narratives we have come to associate with Australia during the Great War. The files do not spontaneously appear in the archive, but are, rather, transmuted by those to whom these records passedcensored, edited and transformed as the narrative required. For Rebecca Corney, the records she donated were testament not only to the loss of Hume, but also to the enduring impact of the war on her family, and a legacy of service that extended well beyond the Armistice. In detailing her family's service, she concluded:

So you see I had five of my family at the War, \& was left here alone-after seeing the five transports depart. But I am proud of them all \& we all have suffered-I think the one who was killed in action is best off after all—the others are never the same ... if [the records] really are of value to the Museum-then when the time comes—I shall die happy. ${ }^{86}$

83 Improvised stretcher-bearer's armband, AWM RELAWM12579.001.

84 Letter from Hubert Hume Corney to his mother, 4 December 1916, AWM 2DRL/0947.

85 Note regarding improvised stretcher-bearer's armband, AWM RELAWM12579.002.

86 Letter from Rebecca Corney, 26 November 1936, AWM93 12/11/548. 
This text is taken from Australian Journal of Biography and History: No. 3, 2020, published 2020 by ANU Press, The Australian National University, Canberra, Australia.

doi.org/10.22459/AJBH.2020.06 